\title{
GAYA KEPEMIMPINAN KEPALA SEKOLAH DALAM UPAYA MENINGKATKAN KINERJA GURU DAN TENAGA KEPENDIDIKAN
}

\author{
Lilis Suryani Octavia \\ Jurusan Manajemen Pendidikan, Fakultas Ilmu Pendidikan, \\ Universitas Negeri Surabaya \\ Email: lilissoctavia@gmail.com \\ Siti Ina Savira \\ Jurusan Psikologi, Fakultas Ilmu Pendidikan, \\ Universitas Negeri Surabaya \\ Email: inasavira@yahoo.com
}

\begin{abstract}
Abstrak
Kepemimpinan dalam pendidikan menjadi kunci dalam pelaksanaan pendidikan yang efektif. pemilihan gaya kepemimpinan yang tepat oleh kepala sekolah akan mampu membawa sekolah kearah peningkatan kualitas dan pelayanan. penelitian ini bertujuan untuk mendeskripsikan dan menganalisis tentang gaya kepemimpinan kepala sekolah dalam upaya meningkatkan kinerja guru dan tenaga kependidikan Di SD Negeri Babatan I/456 Surabaya dan menelusuri tentang faktor yang mempengaruhi gaya kepemimpinan kepala sekolah di SD Negeri Babatan I/456 Surabaya. penelitian ini menggunakan pendekatan kualitatif deskriptif dengan rancangan penelitian studi kasus. teknik pengumpulan data yang digunakan adalah observasi terbuka nonpartisipan, wawancara semi terstruktur dan studi dokumentasi. teknik dalam keabsahan data menggunakan kredibiltas, transferbilitas, dependabilitas dan konfirmabilitas. Hasil penelitian dapat dijelaskan sebagai berikut: (1) gaya kepemimpinan kepala sekolah disimpulkan dari delapan aspek yang telah ditentukan oleh peneliti yaitu: (a) perilaku keseharian kepala sekolah menunjukkan sikap perhatian, terbuka, periang, tegas, bijaksana, disiplin dan komitmen serta memiliki emosi yang stabil; (b) pendelegasian tugas dilakukan dengan adil dan pemberian pengarahan; (c) pengambilan keputusan dilakukan dengan bersama/mufakat; (d) pengawasan yang dilakukan dengan memantau progress secara langsung; (e) pengembangan sekolah meliputi pengembangan sarana dan prasarana sekolah, ekstrakurikuler, pembelajaran dan guru dan tenaga kependidikan; (f) komunikasi yang terbuka dan dua arah dengan menggunakan bahasa yang jelas dan mudah dipahami; (g) motivasi dengan pemberian dorongan/semangat dan memenuhi kebutuhan seluruh personil sekolah dan (h) penghargaan berupa pujian dan ucapan terimakasih. Dalam memimpin kepala sekolah menggunakan gaya kepemimpinan kelompok. Sehingga dapat dipahami dalam upaya meningkatkan kinerja guru dan tenaga kependidikan kepala sekolah melakukan pemberdayaan guru dan tenaga kependidikan, pengembangan kompetensi guru dan tenaga kependidikan, pemberian motivasi dan pemberian penghargaan; (2) faktor yang mempengaruhi gaya kepemimpinan kelompok adalah: (a) diri pemimpin memiliki kepribadian, pengalaman masa lalu, serta harapan yang tinggi kepada seluruh personil sekolah untuk mengembangkan sekolah; (b) ciri atasan yang mengedepankan proses pelaksanaan tugas; (c) ciri bawahan yang menunjukkan semangat dan kemauan untuk berubah; (d) persyaratan tugas dengan memberi pengarahan mengenai kejelasan tugas; (e) iklim organisasi dan kebijakan mampu membantu meningkatkan kualitas sumber daya manusia di lingkungan sekolah.
\end{abstract}

Kata Kunci: gaya kepemimpinan, kinerja guru, kinerja tenaga kependidikan

\section{PENDAHULUAN}

Pendidikan di indonesia memegang peran yang sangat penting dalam pembangunan bangsa, khususnya pembangunan manusia. Pembangunan manusia seutuhnya tidak terlepas dari peran serta masyarakat, dan berbagai lembaga di bidang pendidikan. Hasil penilaian dari PISA (Programme For International Assessment) yang dikoordinasikan oleh OECD (Organization For Economic Cooperation And Development) yang berkedudukan di paris perancis dalam (www.bcc.com) mengemukakan bahwa mutu pendidikan di indonesia "mendudukui peringkat ke 69 dari 76 negara". Hal ini menerangkan bahwa mutu pendidikan di indonesia menempati urutan 8 terbawah, dan ini menunjukkan mutu pendidikan di indonesia masih sangat rendah dibanding negara tetangga singapura yang menempati urutan pertama. Sehingga lembaga pendidikan dituntut mampu melaksanakan fungsi manajemen sekolah 
dengan baik agar mampu mengatasi permasalahan tersebut, salah satunya adalah dengan adanya kepemimpinan yang baik dari kepala sekolah.

Robbin (Rohmat, 2010:39) mengemukakan bahwa, "leadership is ability to influence a group toward the achievment goals". Kepemimpinan dibutuhkan untuk mempengaruhi suatu kelompok ke arah tercapainya tujuan. Untuk mencapai sebuah tujuan organisasi, maka kepemimpinan mutlak harus dilakukan oleh seorang pimpinan organisasi. Dalam mewujudkan suatu organisasi yang baik seorang pemimpin perlu memiliki gaya kepemimpinan sebagai alat dalam mempengaruhi bawahan untuk mencapai tujuan organisasi.

Kepala sekolah di SD Negeri Babatan I/456 Surabaya menerapkan pola kepemimpinan yang tak biasa. Kepala sekolah merangkul semua personil sekolah untuk terlibat dalam kegiatan sekolah. Meski keberadaan kepala sekolah terbilang baru namun kepala sekolah mampu melakukan perubahan secara berkesinambungan untuk memajukan dan meningkatkan kualitas dan pelayanan sekolah. Meski berada di bawah naungan lembaga besar seperti Unit Pelaksana Teknis Daerah (UPTD) dan Dinas Pendidikan Kota Surabaya, kepala SD Negeri Babatan I/456 Surabaya tetap kreatif dan inovatif mengadakan program-program baru yang mampu meningkatkan kualitas sekolah khususnya personil sekolah. Kepala sekolah memanfaatkan lembaga-lembaga yang menaungi sekolah secara maksimal seperti melakukan konsultasi.

Hasil penelitian Samani (Kusmintardjo, 2003:8), menunjukkan bahwa, pola menajamen kepala sekolah, khususnya sekolah negeri, cenderung bersifat administratif dan sekedar melaksanakan kebijakan dari atas, dan tidak risau apakah kebijakan tersebut sesuai atau tidak dengan target pengembangan sekolah. Peran penting kepala sekolah dalam membina dan meningkatkan kinerja guru dan tenaga kependidikan seharusnya tidak hanya mampu melakukan pembinaan administratif, tetapi juga mampu melakukan pembinaan profesionalitas dengan meningkatkan kinerja guru dan tenaga kependidikan. Oleh karena itu gaya kepemimpinan kepala sekolah dalam upaya meningkatkan kinerja guru dan tenaga kependidikan menjadi hal yang sangat menarik untuk dijadikan fokus penelitian secara mendalam, maka peneliti akan mengadakan penelitian tentang "Gaya kepemimpinan kepala sekolah dalam

\section{upaya meningkatkan kinerja guru dan tenaga kependidikan)"}

Dengan fokus penelitian yang diambil: (1) mendeskripsikan dan menganalisis tentang gaya kepemimpinan kepala sekolah dalam upaya meningkatkan kinerja guru dan tenaga kependidikan di SD Negeri Babatan I/456 Surabaya; (2) menelusuri tentang faktor yang mempengaruhi gaya kepemimpinan kepala sekolah di SD Negeri Babatan I/456 Surabaya.

\section{METODE}

Pendekatan yang digunakan dalm penelitian ini adalah pendekatan kualitatif deskriptif dengan rancangan studi kasus. Data dan sumber data pada penelitian ini diperoleh dari data dari hasil wawancara kepada informan, dan data-data lainnya berupa dokumentasi arsip-arsip serta foto-foto yang menunjang data utama. Teknik pengumpulan data pada penelitian ini menggunakan observasi terbuka non-partisipan, wawancara semi terstruktur dan studi dokumentasi. Teknik analisis data kualitatif ini dilakukan secara interaktif. Aktivitas dalam analisis data pada penelitian ini adalah koleksi data, reduksi data, penyajian data, dan yang terakhir adalah kesimpulan.

\section{HASIL DAN PEMBAHASAN}

Gaya kepemimpinan kepala SD Negeri Babatan I/456 Surabaya menunjukkan bahwa kepala sekolah berorientasi pada tugas dan bawahan engan menciptakan pola hubungan yang baik. Berdasarkan temuan penelitian di SD Negeri Babatan I/456 Surabaya menunjukkan bahwa: (1) kepala sekolah menerapkan gaya kepemimpinan yang yang diidentifikasi dari delapan aspek yaitu: (a) perilaku keseharian menunjukkan bahwa kepala sekolah memiliki sikap yang perhatiann, disiplin, inisiatif, terbuka, bijaksana, memiliki emosi yang stabil. Temuan penelitian tersebut sesuai dengan gaya kepemimpinan tim/kelompok menurut Northouse (2013:281) yang mengemukakan bahwa kepemimpinan tim bersifat komplek, sehingga pemimpin harus belajar terbuka dan objektif dalam memahami dan mendiagnosis masalah tim dan ahli dalam memilih tindakan yang paling sesuai untuk membantu pencapaian tujuan tim. Sedangkan emosi yang stabil merujuk pada gaya kepemimpinan demokrasi menurut Usman 
(2014:319), kepemimpinan demokratis yang menghargai pendapat orang, siap berbeda, dan perbedaan tidak untuk dipertentangkan, tetapi untuk didapatkan hikmahnya; (b) pendelegasian tugas dilakukan secara adil dan dengan memberikan penghrgaan terlebih dahulu. Temuan penelitian tersebut sesuai dengan beberapa teori mengenai gaya kepemimpinan. Pertama, gaya kepemimpinan tim/kelompok menurut Northouese (2013:279) yang mengemukakan bahwa tindakan kepemimpinan tugas internal menyangkut keterampilan pembentukan struktur untuk hasil dengan melakukan peerencanaan, memperkirakan, menjelaskan peran dan mendelegasikan tugas secara jelas. Kedua, gaya kepemimpinan situasional menuurt Hersey And Blanchard (Thoha, 2015:66-67) dalam bentuk delegasi pemimpin mendiskusikan masalah bersama dengan bawahan hingga tercapai sebuah kesepakatan untuk mendelegasikan tugas kepada bawahan. Bawahan memiliki kontrol untuk memutuskan bagaimana cara pelaksanaan tugas. Ketiga, gaya kepemimpinan kontingensi menurut Thoha (2015:38) Mengemukakan bahwa tugas-tugas dan semua yang berhubungan dengannya ditentukan dengan jelas.

Aspek selanjutnya, (c) pengambilan keputusan dilakukan secara bersama/musyawarah dengan melibatkan seluruh personil sekolah dan orang tua dari peserta didik. Temuan tersebut sesuai dengan gaya kepimpinan demokrasi menurut Hadari dan Nawawi (2012:101) yang mengemukakan bahwa gaya kepemimpinan ini dalam mengambil keputusan-keputusan mementingkan musyawarah. Kedua, gaya kepemimpinan tim/kelompok menurut Northouse (2013:279-280) yang mengemukakan bahwa tindakan kepemimpinan tugas internal memfasilitasi pembuatan keputusan dengan koordinasi, mengkombinasikan, berfokus pada tujuan dengan menjelaskan dan mendapatkan kesepakatan dalam pengambilan keputusan. Sedangkan tindakan kepemimpinan hubungan internal tercipta dengan melakukan kolaborasi melibatkan dan memasukkan anggota tim dalam pengambilan keputusan. Ketiga, teori komariah dan Triatna (2010:75) mengenai gaya kepemimpinan transaksional yang menjelaskan bahwa pemimpin terlibat dalam aspek-aspek procedural managerial yang metodologis dan fisik. Hal tersebut menjelaskan bahwa pemimpin selalu terlibat dalam setiap kegiatan di sekolah yang bersifat prosedural; (d) pengawasan dilakukan dengan melakukan kontrol atas keputusan yang diambil dengan memantau progress dari setiap tugas. Karakteristik tersebut merujuk pada gaya kepemimpinan tim/kelompok yang dikemukakan oleh Northouse (2013:280) bahwa tindakan kepemimpinan tugas internal selalu melakukan kontrol atas keputusan yang telah diambil; (e) pengembangan sekolah dilakukan secara bertahap dan berkesinambungan dengan komponen pengembangan meliputi, pengembangan pembelajaran, ekstrakurikuler, sarana dan prasarana, serta pengembangan guru dan tenaga kependidikan. Temuan penelitian tersebut sesuai dengan beberapa teori mengenai gaya kepemimpinan. Pertama gaya kepemimpinan tim/kelompok Northouse (2013:280) bahwa bila setelah memantau kinerja tim pemimpin melihat bahwa anggota tim tidak memiliki keterampilan yang diperlukan untuk tugas, maka pemimpin bisa memilih intervensi untuk mendidik anggota tim atau memberi mereka keterampilan atau pengembangan profesional (pelatihan) yang diperlukan. Sedangkan tindakan kepemimpinan hubungan internal menjelaskan bahwa pemimpin memberikan pelatihan anggota tim dalam keterampilan antar pribadi. Kedua, gaya kepemimpinan visioner menurut Komariah dan Triatna (2010:82) bahwa kepala sekolah memiliki antusiasme terhadap perkembangan lembaga yang dipimpinnya. Ketiga gaya kepemimpinan transformasional dari Yulk (2015:316) yang mengemukakan bahwa dalam melakukan mengembangan individual pemimpin memberikan dukungan, dorongan dan pelatihan bagi pengikut.

Aspek selanjutnya adalah (f) komunikasi yang dilakukan secara terbuka dan dua arah. Temuan penelitian tersebut sesuai dengan beberapa teori mengenai gaya kepemimpinan. Pertama gaya kepemimpinan demokrasi menuurt Usman (2014:319) gaya kepemimpinan ini mendorong kelompok untuk berdiskusi dan berpartisipasi. Kedua, gaya kepemimpinan tim/kelompok menurut Northouse (2013:280) dalam pengambilan keputusan kepala sekolah melakukan koordinasi dan mediasi; (g) motivasi dengan memberikan dorongan semangat dan pemenuhan kebutuhan guru dan tenaga kependidikan. Pertama, gaya kepemimpinan demokrasi menurut Aini (2010:35), yang mengemukakan bahwa pemimpin bersikap aktif dalam menggerakkan dan memotivasi bawahan. Kedua, gaya kepemimpinan tim/kelompok menurut Northouse (2013:280), yang 
memaparkan bahwa tindakan kepemimpinan hubungan internal dengan memuaskan kebutuhan setiap anggota. Hasil tersebut menunjukkan bahwa kepala sekolah telah berusaha dan memenuhi kewajibannya sebagai motivator bagi bawahan/seluruh personil sekolah. Ketiga, gaya kepemimpinan Path Goal menurut Northouse (2013:131), membuat pemimpin memotivasi bawahan untuk mencapai tujuan yang telah ditetapkan. Keempat, teori Yulk (2015:316) mengenai gaya kepemimpinan transformasional yang menjelaskan bahwa pemimpin memberikan motivasi/dorongan kepada bawahan untuk melakukan lebih dari yang diharapkan dan lebih sukses dari pemimpinnya; dan (h) penghargaan yang diberikan berupa pujian dan ucapan terimakasih. Gaya kepemimpinan demokratis menurut hasil studi dari Lewin Et.Al (Usman, 2014:319) yang mencoba untuk bersikap objektif dalam memuji dan mengkritik. Sehingga dapat penghargaan yang diberikan oleh kepala sekolah berupa pujian mampu mempengaruhi semangat kerja guru dan staf untuk terus memperbaiki diri. Pemaparan tersebut diatas dapat diringkas dalam tabel sebagai berikut.

Tabel 1. Ringkasan pembahasan

\begin{tabular}{|c|c|c|}
\hline \multirow[b]{2}{*}{$\begin{array}{c}\text { Aspek/Karakt } \\
\text { eristik }\end{array}$} & \multicolumn{2}{|c|}{ Gaya kepemimpinan } \\
\hline & $\begin{array}{l}\text { Temuan di } \\
\text { lapangan }\end{array}$ & $\begin{array}{c}\text { Gaya } \\
\text { kepemimpi } \\
\text { nan }\end{array}$ \\
\hline $\begin{array}{l}\text { Perilaku } \\
\text { keseharian }\end{array}$ & $\begin{array}{l}\text { Perhatian, terbuka, } \\
\text { periang, tegas, } \\
\text { bijaksana disiplin } \\
\text { dan komitmen } \\
\text { serta memiliki } \\
\text { emosi yang stabil. }\end{array}$ & $\begin{array}{l}\text { Kelompok/ti } \\
\mathrm{m} \\
\text { Visioner } \\
\text { Demokrasi }\end{array}$ \\
\hline $\begin{array}{l}\text { Pendelegasian } \\
\text { tugas }\end{array}$ & $\begin{array}{l}\text { Pendelegasian } \\
\text { tugas dilakukan } \\
\text { secara adil, merata } \\
\text { dan disesuaikan } \\
\text { dengan bidang } \\
\text { keahlian, } \\
\text { memberikan } \\
\text { pengarahan } \\
\text { terlebih dahulu, } \\
\text { pemberian } \\
\text { tanggung jawab } \\
\text { dengan melibatkan } \\
\text { dan } \\
\text { memberdayakan } \\
\text { seluruh personil }\end{array}$ & 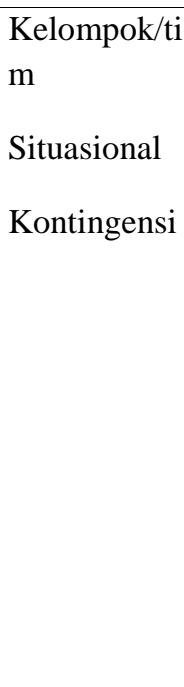 \\
\hline
\end{tabular}

\begin{tabular}{|c|c|c|}
\hline \multirow[b]{2}{*}{$\begin{array}{c}\text { Aspek/Karakt } \\
\text { eristik }\end{array}$} & \multicolumn{2}{|c|}{ Gaya kepemimpinan } \\
\hline & $\begin{array}{l}\text { Temuan di } \\
\text { lapangan }\end{array}$ & $\begin{array}{c}\text { Gaya } \\
\text { kepemimpi } \\
\text { nan }\end{array}$ \\
\hline & sekolah. & \\
\hline $\begin{array}{l}\text { Pengambilan } \\
\text { Keputusan }\end{array}$ & $\begin{array}{l}\text { Bersama/mufakat } \\
\text { dengan } \\
\text { mengundang } \\
\text { seluruh personil } \\
\text { sekolah, } \\
\text { pengambilan } \\
\text { keputusan bersama } \\
\text { melalui kegiatan } \\
\text { rapat dengan } \\
\text { memberikan } \\
\text { informasi dari } \\
\text { lembaga yang } \\
\text { menaungi sekolah } \\
\text { (dinas pendidikand } \\
\text { an uptd) untuk } \\
\text { kemudian } \\
\text { dipecahkan/dicari } \\
\text { solusi secara } \\
\text { bersama, } \\
\text { melakukan } \\
\text { koordinasi dengan } \\
\text { pembagian tugas, } \\
\text { kepala sekolah } \\
\text { selalu terlibat } \\
\text { dalam } \\
\text { pengambilan } \\
\text { keputusan. }\end{array}$ & 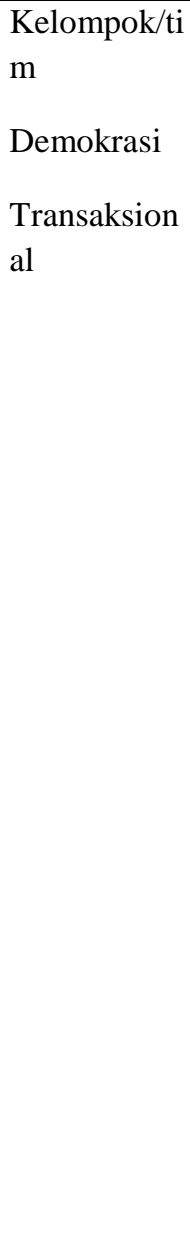 \\
\hline Pengawasan & $\begin{array}{l}\text { Guru: supervisi } \\
\text { administrasi dan } \\
\text { supervisi } \\
\text { pembelajaran } \\
\text { (kunjungan kelas) } \\
\text { Tenaga } \\
\text { kependidikan } \\
\text { (staf): melakukan } \\
\text { kontrol/pemantaua } \\
\text { n secara langsung } \\
\text { dengan } \\
\text { menanyakan } \\
\text { progress dari tugas } \\
\text { yang telah } \\
\text { dikerjakan. }\end{array}$ & $\begin{array}{l}\text { Kelompok/ti } \\
\mathrm{m}\end{array}$ \\
\hline $\begin{array}{l}\text { Pengembangan } \\
\text { Sekolah }\end{array}$ & $\begin{array}{l}\text { Memiliki } \\
\text { antusiasme dalam } \\
\text { mengembangkan }\end{array}$ & $\begin{array}{l}\text { Kelompok/ti } \\
\mathrm{m}\end{array}$ \\
\hline
\end{tabular}




\begin{tabular}{|c|c|c|}
\hline \multirow[b]{2}{*}{$\begin{array}{c}\text { Aspek/Karakt } \\
\text { eristik }\end{array}$} & \multicolumn{2}{|c|}{ Gaya kepemimpinan } \\
\hline & $\begin{array}{l}\text { Temuan di } \\
\text { lapangan }\end{array}$ & $\begin{array}{c}\text { Gaya } \\
\text { kepemimpi } \\
\text { nan }\end{array}$ \\
\hline & $\begin{array}{l}\text { sekolah, seperti } \\
\text { mengembangkan } \\
\text { ekstrakurikuler, } \\
\text { mengembangkan } \\
\text { pembelajaran } \\
\text { dengan berinovasi } \\
\text { membuat program } \\
\text { tambahan belajar } \\
\text { bagi peserta didik } \\
\text { kelas vi, program } \\
\text { sudut baca di tiap- } \\
\text { tiap kelas, gazebo } \\
\text { dan taman baca, } \\
\text { mengembangkan } \\
\text { kualitas guru dan } \\
\text { tenaga } \\
\text { kependidikan guna } \\
\text { meningkatkan } \\
\text { kinerja guru } \\
\text { dengan } \\
\text { memberdayakan } \\
\text { guru dan tenaga } \\
\text { kependidikan, } \\
\text { mengikutsertakan } \\
\text { guru dan tenaga } \\
\text { kependidikan } \\
\text { dalam kegiatan } \\
\text { pelatihan- } \\
\text { pelatihan, } \\
\text { workshop, } \\
\text { pembinaan serta } \\
\text { bekerjasama } \\
\text { dengan lembaga- } \\
\text { lembaga dan } \\
\text { perusahaan- } \\
\text { perusahaan yang } \\
\text { mampu } \\
\text { menciptakan }\end{array}$ & $\begin{array}{l}\text { Visioner } \\
\text { Transformas } \\
\text { ional }\end{array}$ \\
\hline Komunikasi & $\begin{array}{l}\text { Komunikasi } \\
\text { terbuka, } \\
\text { komunikasi dua } \\
\text { arah dengan } \\
\text { menerima } \\
\text { konsultasi, ide-ide } \\
\text { dan menerima dan } \\
\text { memberi kritik dan } \\
\text { saran. }\end{array}$ & 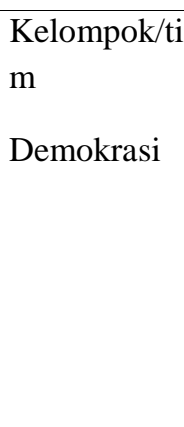 \\
\hline
\end{tabular}

\begin{tabular}{|c|c|c|}
\hline \multirow[b]{2}{*}{$\begin{array}{c}\text { Aspek/Karakt } \\
\text { eristik }\end{array}$} & \multicolumn{2}{|c|}{ Gaya kepemimpinan } \\
\hline & $\begin{array}{l}\text { Temuan di } \\
\text { lapangan }\end{array}$ & $\begin{array}{c}\text { Gaya } \\
\text { kepemimpi } \\
\text { nan }\end{array}$ \\
\hline Motivasi & $\begin{array}{l}\text { Memenuhi } \\
\text { kebutuhan guru } \\
\text { dan tenaga } \\
\text { kependidikaan } \\
\text { seperti makan dan } \\
\text { minum, } \\
\text { memberikan rasa } \\
\text { aman, memberikan } \\
\text { kenyamanan, } \\
\text { menghargai setiap } \\
\text { individu dengan } \\
\text { memberikan } \\
\text { dorongan } \\
\text { semangat, } \\
\text { memenuhi } \\
\text { kebutuhan } \\
\text { pembelajaran. }\end{array}$ & 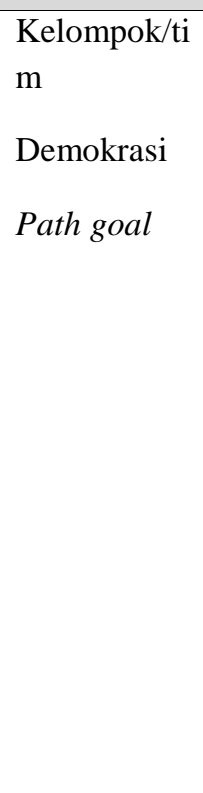 \\
\hline Penghargaan & $\begin{array}{l}\text { Memberikan } \\
\text { pujian dan ucapan } \\
\text { terimakasih }\end{array}$ & Demokrasi \\
\hline $\begin{array}{l}\text { Dalam } \\
\text { ada kompon } \\
\text { komponen yar } \\
\text { gaya kepemin } \\
\text { diri kepala s } \\
\text { dalam dunia } \\
\text { menjabat seb } \\
\text { sekolah neger } \\
\text { pernah menjab } \\
\text { lima tahun da } \\
\text { melakukan ku } \\
\text { pendidikan } \\
\text { terdahulu kep } \\
\text { hubungan der } \\
\text { tersebut sesu } \\
\text { (2009:291) y } \\
\text { pemimpin per } \\
\text { bawahan/berpt } \\
\text { tidak menutı } \\
\text { menerapkan \& } \\
\text { pada bawahan } \\
\text { lembaga yan̨ } \\
\text { Pendidikan K } \\
\text { Teknis Daera } \\
\text { langsung m } \\
\text { Sehingga peril } \\
\text { nada tugas }\end{array}$ & $\begin{array}{l}\text { emilihan gaya keper } \\
\text { yang mempeng } \\
\text { turut andil dalam } \\
\text { inan kepala sekolal } \\
\text { rolah yang memilil } \\
\text { pendidikan yaitu } \\
\text { gai kepala sekolah } \\
\text { di surabaya, kepala } \\
\text { t sebagai bendahara } \\
\text { mengunjungi nege } \\
\text { jungan dan memp } \\
\text { sana. Dalam kep } \\
\text { la sekolah lebih } \\
\text { gan bawahan. Tem } \\
\text { i dengan pendap } \\
\text { ng mengemukakan } \\
\text { h sukses dengan ca } \\
\text { at pada karyawan di } \\
\text { kemungkinan/cen } \\
\text { ya yang sama yai } \\
\text { (b) ciri atasan dalam } \\
\text { menaungi sekolah } \\
\text { ta Surabaya dan } \\
\text { yang akan men } \\
\text { genai perkemban } \\
\text { ku atasan menunjukk } \\
\text { no ditakankan nan }\end{array}$ & $\begin{array}{l}\text { impinan akan } \\
\text { ruhinya. (2) } \\
\text { nempengaruhi } \\
\text { meliputi: (a) } \\
\text { pengalaman } \\
\text { elain pernah } \\
\text { di beberapa } \\
\text { sekolah juga } \\
\text { ekolah selama } \\
\text { korea untuk } \\
\text { lajari budaya } \\
\text { mimpinannya } \\
\text { hengutamakan } \\
\text { an penelitian } \\
\text { Chatterjee } \\
\text { bahwa jika } \\
\text { a menghargai } \\
\text { hasa yang lalu } \\
\text { erung untuk } \\
\text { berorientasi } \\
\text { hal ini adalah } \\
\text { yaitu Dinas } \\
\text { nit Pelaksana } \\
\text { antau secara } \\
\text { an sekolah. } \\
\text { n berorientasi } \\
\text { nelaksanaan }\end{array}$ \\
\hline
\end{tabular}


tugas. Seperti yang dipaparkan kepala sekolah bahwa kota surabaya menempati peringkat 33 di Indonesia dengan predikat pelaksanaan ujian nasional terjujur. Sehingga kepala sekolah di seluruh surabaya dituntut dan diharapkan untuk melaksanakan ujian nasional dengan jujur. Dengan demikian kepala sekolah di SD Negeri Babatan I/456 Surabaya juga berorientasi pada proses dengan menyiapkan guru dan peserta didik sebaik mungkin dalam menghadapi ujian nasional. Temuan penelitian tersebut sesuai dengan pendapat Chatterjee (2009:291) Yang mengemukakan bahwa harapan dan perilaku atasan akan tercermin dalam tindakan atasan, misalnya ketika atasan memberikan penghargaan kepada organisasi seperti bonus dan promosi akan mempengaruhi manager dibawahnya, atau atasan yang berorientasi pada tugas akan menyebabkan pimpinan juga akan menggunakan gaya tersebut yang serupa.

Faktor selanjutnya adalah (c) ciri bawahan perilaku bawahan menunjukkan belum melaksanakan sistem pengelolaan sekolah yang benar, hal ini tercermin dari tindakan-tindakan guru dan staf yang tidak disiplin mengenai jam pulang. Sehingga dapat dipahami bahwa seluruh personil sekolah belum melaksanakan dan mematuhi peraturan yang berlaku. Perilaku bawahan yang seperti ini membutuhkan pengarahan dan pemodelan diri pemimpin sebagai panutan/contoh agar mampu merubah pola/kebiasaan sebelumnya. Temuan penelitian tersebut sesuai dengan pendapat Chatterjee (2009:291) yang mengemukakan keterampilan, pelatihan dan sikap bawahan juga mempengaruhi pemilihan gaya kepemimpinan; (d) persyaratan tugas yang diberikan kepala sekolah secara adil dan merata yang disesuaikan dengan skill/kemampuan guru dan staf. Pada umumnya personil sekolah lebih menyukai adanya pengarahan terlebih dahulu dari kepala sekolah mengenai kejelasan tugas yang menyangkut bagaimana tugas dilaksanakan. Temuan penelitian tersebut sesuai dengan pendapat Chatterjee (2009:291) yang mengemukakan bahwa, jika sifat dan tanggung jawab dari bawahan akan mempengaruhi gaya kepemimpinan yang digunakan oleh pemimpin. Seperti pelaksanaan setiap tugas bawahan akan mempengaruhi gaya pemimpin, misalnya bawahan yang bekerja pada pengolahan data menyukai pengarahan yang lebih berorientasi kepada tugasnya; dan yang terakhir adalah (e) iklim organisasi dan kebijakan yang dilakukan oleh kepala sekolah adalah dengan berusaha memenuhi standar dengan mendisiplinkan administrasi sekolah. Pemberian pujian sebagai salah satu bentuk penghargaan dan apresiasi atas hasil kerja karyawan mampu mendorong menciptakan iklim organisasi yang kondusif. Temuan penelitian tersebut sejalan dengan pendapat Chatterjee (2009:291) yang mengemukakan bahwa, iklim dan kebijakan organisasi mempengaruhi harapan dan perilaku bawahan, misalnya kebijakan pemberian penghargaan, imbalan dengan skala gaji yang ditunjang dengan insentif lain (dana pensiun, bonus, cuti) akan mempengaruhi motivasi kerja bawahan. Dalam hal ini kepala sekolah tidak memberikan imbalan berupa insentif namun hanya berupa ucapan dan pujian. Namun pemberian penghargaan yang diberikan oleh kepala sekolah hanya berupa pujian belum memberikan penghargaan berupa cuti/insentif.

\section{PENUTUP}

\section{Simpulan}

Sebagai akhir penelitian dan pembahasan dari bab ini penulis mengungkapkan hasil penelitian dan pembahasan secara keseluruhan dalam bentuk kesimpulan. Sebagai berikut:

1. Gaya kepemimpinan kepala sekolah di SD Negeri Babatan I/456 Surabaya dalam upaya meningkatkan kinerja guru dan tenaga kependidikan menunjukkan ciri-ciri sebagai berikut.

a. Kepala sekolah di SD Negeri Babatan I/456 Surabaya menunjukkan perilaku yang perhatian salah satunya dengan meminjamkan helem, terbuka dan tidak menutupi mengenai aktivitas kepala sekolah, selalu bergembira/periang, tegas dalam bertindak, disiplin dengan mematuhi kebijakan yang telah dibuat dan komitmen untuk tidak melanggar dan menerima konsekuensi apabila melakukan pelanggaran, bijaksana dengan tidak mudah terpengaruh oleh lingkungan dan tidak mudah marah yang menunjukkan kepala sekolah memiliki emosi yang stabil.

b. Pendelegasian tugas yang diberikan oleh kepala sekolah di SD Negeri Babatan I/456 Surabaya dilakukan dengan adil dan memberikan pengarahan terlebih dahulu mengenai kejelasan tugas dan bagaimana 
tugas harus dijalankan kepada guru/tenaga kependidikan yang diberikan tugas.

c. Pengambilan keputusan yang dilakukan oleh kepala sekolah Di SD Negeri Babatan I/456 Surabaya dengan melibatkan seluruh personil sekolah baik guru, tenaga kependidikan, penjaga sekolah, petugas kebersihan, dan tenaga keamaan untuk mencapai keputusan bersama/mufakat. Kepala sekolah juga selalu terlibat dalam setiap pengambilan keputusan baik secara fisik maupun dengan alat komunikasi seperti telepon dan Whatsapp.

d. Pengembangan sekolah yang dilakukan oleh kepala sekolah Di SD Negeri Babatan I/456 Surabaya mencakup beberapa aspek, meliputi pengembangan sarana dan prasarana sekolah, pengembangan pembelajaran, pengembangan ekstrakurikuler, dan pengembangan guru dan tenaga kependidikan yang dilakukan secara bertahap dan berkesinambungan.

e. Pengawasan yang dilakukan oleh kepala sekolah di SD Negeri Babatan I/456 Surabaya berbeda antara guru dan tenaga kependidikan. Pengawasan untuk tenaga kependidikan dilakukan secara langsung dengan memantau progress dari tugas yang diberikan. Sedangkan untuk guru dilakukan supervisi administrasi yang dilakukan setiap awal semester dan supervisi pembelajaran (kunjungan kelas) yang dilakukan pada tiap bulan dengan volume 2-3 orang guru kelas.

f. Komunikasi yang dilakukan oleh kepala sekolah di SD Negeri Babatan I/456 Surabaya dengan komunikasi dua arah, terbuka sehingga tidak ada yang ditutup-tutupi dari staf serta menggunakan bahasa-bahasa yang mudah dipahami oleh bawahan.

g. Motivasi yang diberikan oleh kepala sekolah di SD Negeri Babatan I/456 Surabaya berupa pemenuhan kebutuhan guru dan tenaga kependidikan, baik kebutuhan fisik seperti rasa aman dan rasa nyaman, kebutuhan fisiologi seperti makan dan minum, kebutuhan pembelajaran seperti media pembelajaran, kebutuhan harga diri seperti adanya pengakuan dari kepala sekolah mengenai kemampuan personil sekolah, dan kebutuhan aktualisasi diri seperti memberikan kesempatan untuk menunjukkan kemampuan dan berkembang dalam kegiatan lomba serta tak lupa juga pemberian dorongan/dukungan agar semangat dalam bekerja. h. Penghargaan yang diberikan oleh kepala sekolah di SD Negeri Babatan I/456 Surabaya berupa penghargaan secara lisan seperti ucapan terimakasih dan pujian.

Dari penjabaran tersebut diatas dapat disimpulkan bahwa gaya kepemimpinan yang digunakan oleh kepala sekolah di SD Negeri Babatan I/456 Surabaya cenderung atau lebih dominan menggunakan gaya kepemimpinan kelompok/tim yang diterapkan dalam pengelolaan sekolah. Dari gaya kepemimpinan tersebut mengarah kepada upaya-upaya yang dilakukan oleh kepala sekolah dalam meningkatkan kinerja guru dan tenaga kependidikan meliputi, pemberdayaan (melibatkan personil sekolah dalam pembinaan/rapat, melibatkan dalam pengambilan keputusan, pendelegasian tugas/perintah, kegiatan sekolah), pengembangan kompetensi guru dan tenaga kependidikan (mengikutsertakan dalam pelatihanpelatihan, pembinaan, penataran, workshop, supervisi guru oleh kepala sekolah dan pengawas sekolah, pengawasan terhadap tenaga kependidikan, memanfaatkan organisasi-organsiasi kelompok yang terkait dengan pendidikan), pemberian motivasi bagi guru dan tenaga kependidikan, serta pemberian penghargaan bagi guru dan tenaga kependidikan.

2. Faktor yang mempengaruhi gaya kepemimpinan kepala sekolah meliputi.

a. Ciri pemimpin yang memiliki kepribadian yang disiplin dan memiliki antusiasme dalam mengembangkan sekolah berdasar pada pengalaman dan kemampuan yang dimiliki.

b. Ciri atasan yang berorientasi pada tugas dan menekankan pada proses pelaksanaan tugas untuk ketercapaian hasil yang optimal.

c. Ciri bawahan yang mau berubah dan memiliki harapan dan kemauan tinggi untuk berkembang.

d. Persyaratan tugas dengan memberikan pengarahan mengenai kejelasan tugas terlebih dahulu.

e. Iklim organsiasi yang terbuka dengan pemberian penghargaan berupa pujian.

f. Perilaku dan harapan rekanan tidak memiliki pengaruh karena kepala sekolah tidak membentuk sebuah persahabatan

Dari penjabaran tersebut diatas dapat disimpulkan bahwa faktor yang mempengaruhi gaya kepemimpinan yang digunakan oleh kepala sekolah di SD Negeri Babatan I/456 Surabaya meliputi, ciri 
pemimpin, ciri atasan, ciri bawahan, persyaratan tugas dan iklim organsiasi dan kebijakan. Sedangkan perilaku dan harapan rekanan tidak berpengaruh karena kepala sekolah tidak membentuk sebuah persahabatan di lingkungan sekolah.

\section{Saran}

Berdasarkan hasil penelitian tentang "gaya kepemimpinan kepala sekolah dalam upaya meningkatkan kinerja guru dan tenaga kependidikan (studi kasus di SD Negeri Babatan I/456 Surabaya)" yang telah dilakukan, maka dapat dipaparkan beberapa saran saran yang membangun berdasarkan penelitian yang telah dilakukan, yaitu diantaranya:

1. Untuk meningkatkan kinerja tenaga kependidikan, sebaiknya memberlakukan sistem jurnal harian kepada staf tata usaha dan staf perpustakaan agar memudahkan dalam pemantauan/pengawasan kinerja dari tenaga kependidikan tersebut.

2. Untuk meningkatkan kedisiplinan guru dan tenaga kependidikan, sebaiknya kepala sekolah menerapkan sistem reward dan punishment.

3. Untuk memudahkan pengelolaan sekolah dan tercapainya visi dan misi sekolah, sebaiknya disegerakan membuat rencana pengembangan sekolah (rps) dan rencana strategis (renstra).

4. Untuk meningkatkan dukungan dari masyarakat mengenai program-program sekolah, sebaiknya kepala sekolah mengadakan kegiatan-kegiatan pertemuan dengan orang tua/wali murid untuk lebih mengenalkan diri kepala sekolah dan program-program yang dimiliki sekolah kepada masyarakat luar, sehingga diharapkan akan membuat masyarakat terlibatksecara langsung dalam kegiatan-kegiatan sekolah.

\section{DAFTAR PUSTAKA}

Aini, Niswatul. Gaya Kepemimpinan Kepala Sekolah dalam Meningkatkan Kinerja Guru PAI di SMPN 3 Nganjuk. Malang: Universitas Islam Negeri Maulana Malik Ibrahim Malang. online: (http://lib.uinmalang.ac.id/files/thesis/fullchapte r/04120049.pdf9]. Diakses Pada Tanggal: 8 Desember 2015 Pukul 10.00 WIB).

Chatterjee, Bhaskar. 2009. Human Resource Management A Contemporary Text. New Delhi: Sterling Publisher Private Limited

Komariah, Aan Dan Triatna, Cepi. 2010. Visionary Leadership Menuju Sekolah Efektif. Jakarta: Bumi Aksara

Kusmintardjo. 2003. Kepemimpinan Pembelajaran Kepala Sekolah Dalam Meningkatkan Kienrja Guru Studi Multi Kasus Pada Dua SMU Di Kota Malang. Disertasi tidak Diterbitkan. Malang: Universitas Negeri Malang.

Nawawi, Hadari dan Hadari, M. Martini. 2012. Kepemimpinan Yang Efektif. Yogyakarta: Gadjah Mada University Press

Northouse, Peter G. 2013. Kepemimpinan Teori dan Praktik. Edisi Keenam. Jakarta: Indeks

Rohmat. 2010. Kepemimpinan Pendidikan Konsep Dan Aplikasi. Purwokerto: $\quad$ STAIN Press

Thoha, Miftah. 2015. Kepemimpinan dalam Manajemen. Jakarta: Rajawali Pers

Usman, Husaini. 2014. Manajemen Teori, Praktik dan Riset Pendidikan. Edisi Keempat. Jakarta: Bumi Aksara

Yukl, Gary. 2015. Kepemimpinan dalam Organisasi. Edisi Ketujuh. Jakarta: Indeks 